\title{
Growth of Spirillum lipoferum at Constant Partial Pressures of Oxygen, and the Properties of its Nitrogenase in Cell-free Extracts
}

\author{
By YAACOV OKON, JEFFREY P. HOUCHINS, STEPHAN L. ALBRECHT \\ AND R. H. BURRIS \\ Department of Biochemistry, College of Agricultural and Life Sciences, \\ University of Wisconsin, Madison, Wisconsin 53706, U.S.A.
}

(Received I June 1976)

SUMMAR Y

Spirillum lipoferum, an $\mathrm{N}_{2}$-fixing organism, was grown at constant concentrations of dissolved $\mathrm{O}_{2}$. When supplied with $\mathrm{NH}_{4}{ }^{+}$aerobically, its doubling time was I $\mathrm{h}$; when it fixed $\mathrm{N}_{2}$ microaerophilically, its doubling time was 5.5 to $7 \mathrm{~h}$ and the optimal $P_{\mathrm{O}_{2}}$ for growth was 0.005 to $0.007 \mathrm{~atm}$. At its optimal $P_{\mathrm{O}_{2}}$ for growth on $\mathrm{N}_{2}$, S. lipoferum assimilated 8 to $10 \mathrm{mg}$ nitrogen/g carbon substrate used; its efficiency was less at higher $P_{\mathrm{O}_{2}}$ levels. Nitrogenase in cell-free extracts required $\mathrm{Mg}^{2+}$ and $\mathrm{Mn}^{2+}$, and the Fe-protein was activated by Rhodospirillum rubrum activating factor. The nitrogenase had an optimal $\mathrm{pH}$ of $7 \cdot \mathrm{I}$ to $7 \cdot 4$ and an apparent $K_{\mathrm{m}}$ for acetylene of $0.0036 \mathrm{~atm}$. Extracts of $S$. lipoferum lost their nitrogenase activity on storage at $-\mathrm{I} 8^{\circ} \mathrm{C}$, and activity was restored by adding purified Feprotein from other $\mathrm{N}_{2}$-fixing bacteria.

\section{INTRODUCTION}

The cultural and physiological properties of Spirillum lipoferum ATCC29I45 have been investigated recently (Day \& Döbereiner, ${ }^{1976)}$. This is a $\mathrm{N}_{2}$-fixing bacterium that can associate with roots of several grasses (Döbereiner \& Day, 1976; Von Bülow \& Döbereiner, 1975; Albrecht \& Okon, 1975). It will grow and fix $\mathrm{N}_{2}$ under microaerophilic conditions with malate, succinate, lactate or pyruvate as carbon and energy sources.

This paper describes the growth of $S$. lipoferum at constant $P_{\mathrm{O}_{2}}$ and the properties of nitrogenase in cell-free extracts of this organism.

\section{METHODS}

Spirillum lipoferum ATCC29I45, isolated from the roots of Digitaria decumbens (Döbereiner \& Day, 1976), was grown in 3 or 201 bottles containing 2.7 or 181 , respectively, of the liquid medium of Döbereiner \& Day (1976), modified to the following composition ( $\left.\mathrm{g} \mathrm{1}^{-1}\right)$ : $\mathrm{K}_{2} \mathrm{HPO}_{4}, 6 ; \mathrm{KH}_{2} \mathrm{PO}_{4}, 4$ (these were mixed to a tenth of the final volume and autoclaved separately to avoid precipitation; later the phosphate solution was mixed with the cold medium); $\mathrm{MgSO}_{4} .7 \mathrm{H}_{2} \mathrm{O}, 0.2 ; \mathrm{NaCl}, 0 . \mathrm{I} ; \mathrm{CaCl}_{2}, 0.02 ;$ DL-malic acid, $5 ; \mathrm{NaOH}, 3 ;$ Difco yeast extract, $0 \cdot \mathrm{I}$; and $\left(\mathrm{mg} \mathrm{l}^{-1}\right) \mathrm{FeCl}_{3}$, IO; $\mathrm{NaMoO}_{4} .2 \mathrm{H}_{2} \mathrm{O}, 2 ; \mathrm{MnSO}_{4}, 2 \cdot \mathrm{I} ; \mathrm{H}_{3} \mathrm{BO}_{3}, 2.8$; $\mathrm{Cu}\left(\mathrm{NO}_{3}\right)_{2} \cdot 3 \mathrm{H}_{2} \mathrm{O}, 0.04 ; \mathrm{ZnSO}_{4} \cdot 7 \mathrm{H}_{2} \mathrm{O}, 0.24$; the final $\mathrm{pH}$ was adjusted to $6 \cdot 8$.

The inoculum was $10 \%$ of the total volume of the culture and was grown aerobically at $30{ }^{\circ} \mathrm{C}$ in medium supplemented with $0.05 \%(\mathrm{w} / \mathrm{v}) \mathrm{NH}_{4} \mathrm{Cl}$. The culture had an initial $E_{560}$ 
of 0.09 to $0.1 \mathrm{I}$. The culture was sparged with a sterile mixture of $\mathrm{N}_{2}$ and air, and was stirred with a magnetic bar; a thermistor probe in a well in the culture bottle controlled an external infrared lamp that maintained a temperature of $30{ }^{\circ} \mathrm{C}$. A constant concentration of dissolved $\mathrm{O}_{2}$, in equilibrium with 0.002 to 0.018 atm $\mathrm{O}_{2}$, was maintained by using an $\mathrm{O}_{2}$-stat; an immersed sterilizable $\mathrm{O}_{2}$ electrode (Borkowski \& Johnson, 1967) was used to measure the $\mathrm{O}_{2}$ concentration and to control the $\mathrm{O}_{2}$-stat.

Growth of the culture was followed by measuring $E_{560}$. After removing the organisms by centrifuging the culture at $5000 \mathrm{~g}$ for $10 \mathrm{~min}$, total carbon in the supernatant was determined by the method described by Umbreit, Burris \& Stauffer (1972a) using malic acid as a standard. The pellet was dried at $80^{\circ} \mathrm{C}$ for $24 \mathrm{~h}$ and weighed, and total nitrogen in the organisms was measured (Umbreit et al., $1972 b$ ).

Acetylene reduction in the growing culture was measured by transferring $2 \mathrm{ml}$ samples with a syringe into $2 \mathrm{I} \mathrm{ml} \mathrm{serum} \mathrm{bottles,} \mathrm{stoppered} \mathrm{with} \mathrm{rubber} \mathrm{closures,} \mathrm{that} \mathrm{previously} \mathrm{had}$ been evacuated and filled with $\mathrm{N}_{2}$ and $\mathrm{O}_{2}$ to match the $P_{\mathrm{O}_{2}}$ of the culture. Acetylene, to a final pressure of $0.1 \mathrm{I} \mathrm{atm}$, was then added. The bottles were incubated at $30{ }^{\circ} \mathrm{C}$ and shaken at $\mathrm{I} 50$ cycles $\mathrm{min}^{-1}$ in a water bath, and the amount of ethylene formed by acetylene reduction was determined by gas chromatography using a flame ionization detector (Burris, 1974).

Spirillum lipoferum was harvested during the exponential growth phase under anaerobic conditions and centrifuged anaerobically at $8000 \mathrm{~g}$ for Io min at $4{ }^{\circ} \mathrm{C}$. The pellet $(\mathrm{I} \cdot 5$ to $2 \cdot 0 \mathrm{~g}$ wet wt/l medium) was stored in liquid $\mathrm{N}_{2}$ without any apparent loss in nitrogenase activity.

Crude cell-free extracts of $S$. lipoferum were prepared under anaerobic conditions in $300 \mathrm{~mm}$-Tris/ $\mathrm{HCl}$ buffer, $\mathrm{pH} 8.7$ (I g wet wt of cell paste/4 ml buffer), containing dithiothreitol $\left(0 \cdot 1 \mathrm{mg} \mathrm{ml}^{-1}\right)$, DNAase and $\mathrm{Na}$ dithionite. The cells were broken in a French press at $80000 \mathrm{kPa}$. The final $\mathrm{pH}$ of the extract ranged from 7.5 to $8 \cdot 1$, depending on the batch of cells. When the buffer concentration was decreased or the buffer to cell ratio was lowered, the $\mathrm{pH}$ dropped below $5^{\circ} \mathrm{O}$ and nitrogenase activity was lost completely. Osmotic shock treatment (Shah, Davis \& Brill, 1972) caused only poor disruption of the organisms and yielded nitrogenase of low activity.

The extract was centrifuged anaerobically at $10000 \mathrm{~g}$ for $30 \mathrm{~min}$ at $4{ }^{\circ} \mathrm{C}$, and this produced a turbid pinkish-brown supernatant (crude extract) and a white pellet. When this supernatant was centrifuged at $48000 \mathrm{~g}$ for $2 \mathrm{~h}$ at $4{ }^{\circ} \mathrm{C}$, it gave a clear supernatant (soluble nitrogenase, brown colour with the pink of cytochromes) and a dark brown pellet (membrane fraction).

Nitrogenase activity was estimated by production of ethylene from acetylene in $2 \mathrm{I} \mathrm{ml}$ bottles that had been shaken under anaerobic conditions $\left(\mathrm{N}_{2}\right.$ or $\left.\mathrm{H}_{2}\right)$ at $30{ }^{\circ} \mathrm{C}$ in a water bath. For optimal activity, the reaction mixture (total vol. I.35 ml) contained: $100 \mu \mathrm{mol}$ HEPES [2-( $N$-2-hydroxyethylpiperazine- $N^{\prime}$-yl)ethanesulphonic acid] buffer, $\mathrm{pH} 7 \cdot 3 ; 5 \mu \mathrm{mol}$ ATP, $40 \mu \mathrm{mol}$ creatine phosphate, $0.2 \mathrm{mg}$ creatine kinase $\mathrm{ml}^{-1} ; 14.5 \mathrm{mM}-\mathrm{MgCl}_{2} ; 0.44 \mathrm{~mm}-$ $\mathrm{MnCl}_{2} ; 5 \mathrm{~mm}-\mathrm{Na}$ dithionite; and $0.3 \mathrm{ml}$ (approximately $2 \mathrm{mg}$ protein) enzyme extract. Nitrogenase specific activity was expressed as nmol ethylene produced $\min ^{-1}$ (mg protein $)^{-1}$. Protein concentration was determined by the microbiuret method (Goa, 1953).

The Fe-proteins of nitrogenases used in cross-testing for enzymic activity with the nitrogenase from $S$. lipoferum were purified by the following colleagues: R. Hageman, Azotobacter vinelandii; P. Ludden, Rhodospirillum rubrum; D. W. Emerich, Bacillus polymyxa and Clostridium pasteurianum. The purification methods will be published elsewhere. 


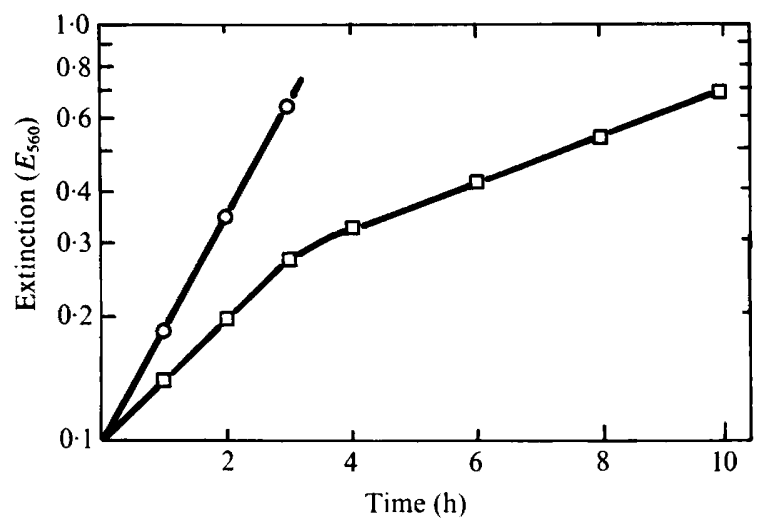

Fig. I. Typical growth curves of $S$. lipoferum grown at 0.2 atm $\mathrm{O}_{2}$ in the presence of $0.1 \% \mathrm{NH}_{4} \mathrm{Cl}$ (O), and on $\mathrm{N}_{2}$ in a nitrogen-free medium at a $P_{\mathrm{O}_{2}}$ of 0.005 to 0.007 atm and a $P_{\mathrm{N}_{2}}$ of about $0.99 \mathrm{~atm}(\square)$.

Table $\mathrm{I}$. Effect of $P_{\mathrm{O}_{2}}$ on doubling time, efficiency and acetylene reduction rates in cultures of $S$. lipoferum grown at constant $P_{\mathrm{O}_{2}}$

Values of the doubling time are the ranges from at least two experiments. Efficiency of nitrogen assimilation was calculated by measuring the total nitrogen content of the culture and the carbon growth substrate consumed at four different times during the exponential phase of growth of the culture when fixing $\mathrm{N}_{2}$ : efficiencies are expressed as $\mathrm{mg}$ nitrogen assimilated $/ \mathrm{g}$ malate consumed.

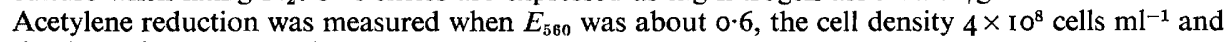
the dry weight $0.5 \mathrm{mg} \mathrm{ml}^{-1}$.

$\begin{array}{cccc}P_{\mathrm{O}_{2}}(\mathrm{~atm}) & \begin{array}{c}\text { Doubling time } \\ (\mathrm{h})\end{array} & \text { Efficiency } & \begin{array}{c}\text { Acetylene reduction } \\ \left(\mathrm{nmol} \mathrm{h}^{-1} \mathrm{ml}^{-1}\right)\end{array} \\ 0.002-0.003 & 9-10 & \mathrm{II} \cdot 9-\mathrm{I} 2.5 & 250-280 \\ 0.005-0.007 & 5 \cdot 5-7 & 8-10 & 280-300 \\ 0.009-0.011 & 7 \cdot 5-8.5 & 2 \cdot 5-4 \cdot 0 & 80-100 \\ 0.014-0.018 & 8.5-9.5 & \mathrm{I} \cdot 2-2 \cdot \mathrm{I} & 50-75\end{array}$

\section{RESULTS AND DISCUSSION}

Spirillum lipoferum grew in an $\mathrm{O}_{2}$-stat at a constant $P_{\mathrm{O}_{2}}$ both on combined nitrogen and under $\mathrm{N}_{2}$-fixing conditions; as the $\mathrm{O}_{2}$ demand of the culture increased, increasing amounts of $\mathrm{O}_{2}$ at a constant $P_{\mathrm{O}_{2}}$ were supplied. Typically, the first phase of growth of $S$. lipoferum at 0.005 to 0.007 atm $\mathrm{O}_{2}$ (bottom curve, Fig. I $\mu=2 \mathrm{~h}$ ), depended on the combined nitrogen present in the yeast extract in the medium, and $\mathrm{NH}_{4} \mathrm{Cl}$ carried over with the inoculum. Saturation of the $\mathrm{NH}_{4} \mathrm{Cl}$-containing medium with $\mathrm{O}_{2}$, at the level in air, at all stages of growth markedly increased the growth rate $(\mu=\mathrm{I} \mathrm{h} \pm \mathrm{IO}$ min; top curve, Fig. I). Thus, $S$. lipoferum is a fast-growing, fully aerobic organism when supplied with combined nitrogen.

Growth rates under $\mathrm{N}_{2}$-fixing conditions during the second phase of growth were slower and depended on $P_{\mathrm{O}_{2}}$ being maintained within a narrow range; $\mu$ was 5.5 to $7 \mathrm{~h}$ at a $P_{\mathrm{O}_{2}}$ of 0.005 to $0.007 \mathrm{~atm}$ (Fig. I, Table I). Though several different $P_{\mathrm{O}_{2}}$ values in the range 0.004 to $0.04 \mathrm{~atm}$ have been reported as optimal for growth and $\mathrm{N}_{2}$ fixation of $S$. lipoferum (Day \& Döbereiner, 1976), none of these values was measured at a constant concentration of dissolved $\mathrm{O}_{2}$.

By using a $10 \%$ inoculum grown on a medium containing $\mathrm{NH}_{4} \mathrm{Cl}$, S. lipoferum could be grown and harvested with an active nitrogenase in $\mathrm{I} 4$ to $\mathrm{I} 6 \mathrm{~h}$; the initial growth for a generation or so after transfer to the nitrogen-free medium was presumed to be on residual $\mathrm{NH}_{4}{ }^{+}$ 


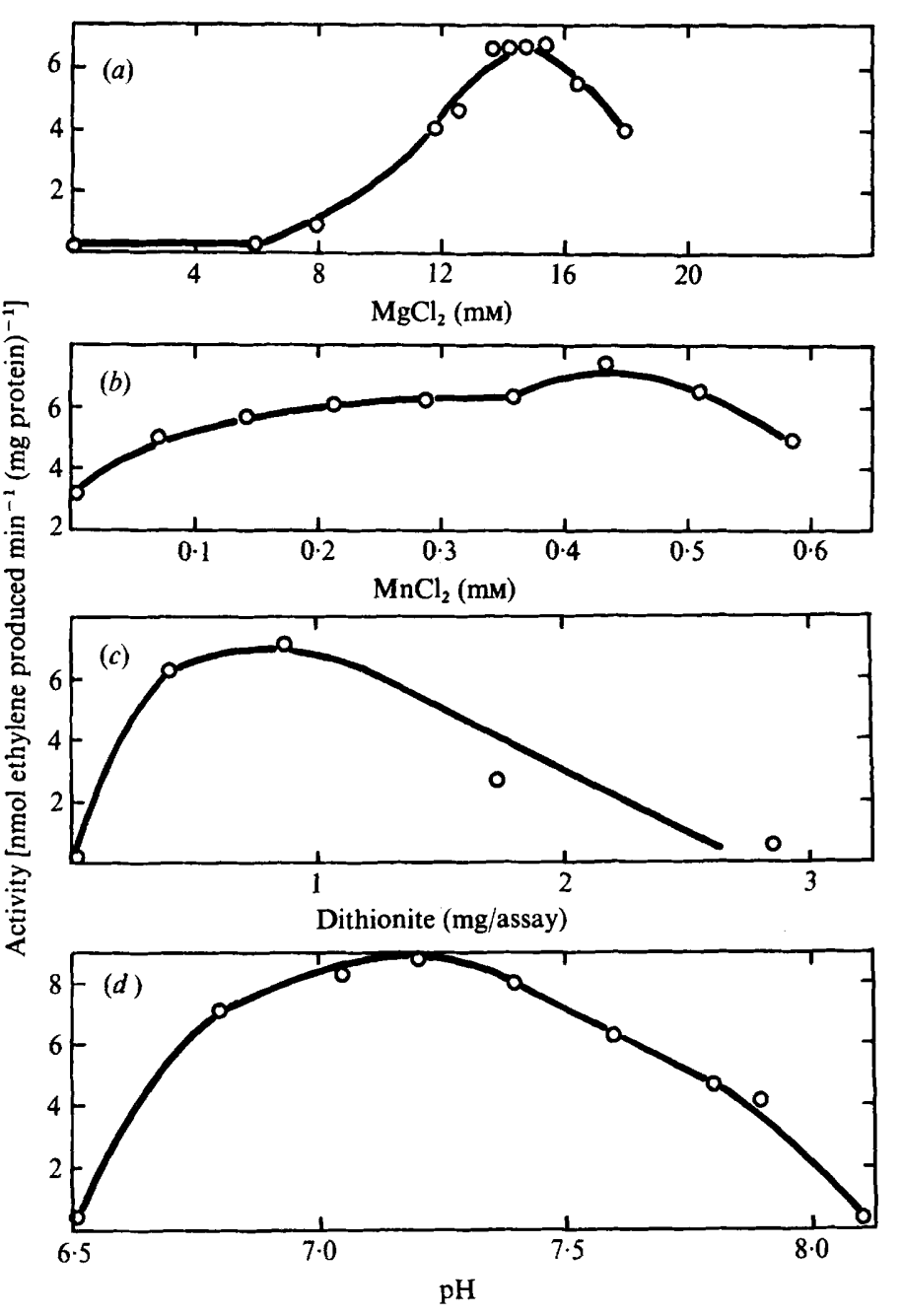

Fig. 2. Effect of (a) $\mathrm{MgCl}_{2},(b) \mathrm{MnCl}_{2}$ (optimal $\mathrm{MgCl}_{2}$ present), (c) dithionite, and (d) $\mathrm{pH}$ on nitrogenase activity of cell-free extracts of $S$. lipoferum.

from the inoculum and after this the culture depended on $\mathrm{N}_{2}$ fixation to support growth.

The $\mathrm{O}_{2}$ concentration in the medium affected the nitrogenase activity, the total nitrogen in the culture, and the utilization and efficiency of use of carbon substrates (Table I). At optimal $P_{\mathrm{O}_{2}}$, the efficiency was 8 to $\mathrm{I}$ o $\mathrm{mg}$ nitrogen fixed/g carbon substrate used, whereas efficiencies were lower at $\mathrm{O}_{2}$ concentrations above the optimal (Table I).

Very high efficiencies of substrate conversion ( 40 to $50 \mathrm{mg}$ cell nitrogen produced/g carbon substrate utilized) have been reported in $\mathrm{O}_{2}$-limited continuous cultures of Azotobacter chroococcum (Postgate, 1971), and by Day \& Döbereiner (1976) in stagnant cultures of $S$. lipoferum on a semi-solid medium. With the same organism under similar conditions, values ranging from Io to 25 have been obtained by Y. Okon et al. (unpublished observations). However, efficiency values of only 3 to 6 were reported by Fedorov \& Kalininskaya (I96I) for a so-called Mycobacterium flavum, a microaerophilic $\mathrm{N}_{2}$-fixing bacterium.

The values for the efficiency of $\mathrm{N}_{2}$-fixation presented here were derived from measurements 


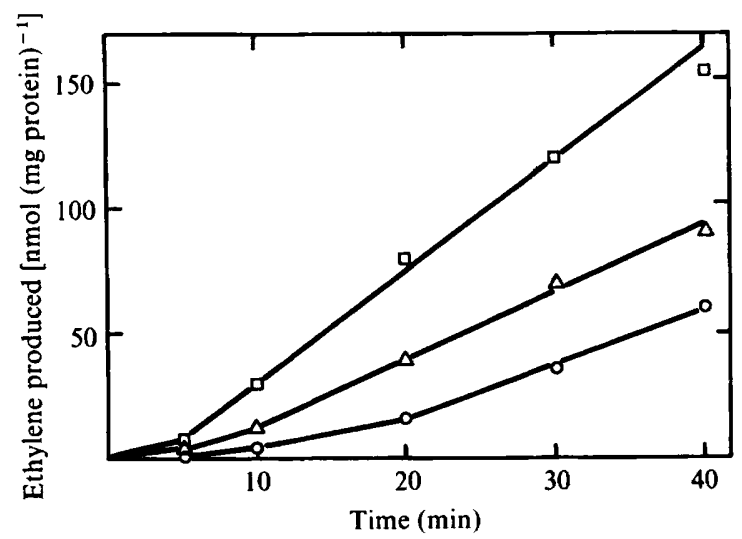

Fig. 3. Time course of acetylene reduction by nitrogenase in cell-free extracts from $S$. lipoferum. The reaction mixture contained $14.8 \mathrm{~mm}-\mathrm{MgCl}_{2}$ and $0.85 \mathrm{mg}$ dithionite per assay: $\square$, plus $0.44 \mathrm{mM}-\mathrm{MnCl}_{2}$ and an activating protein from $R$, rubrum; $\triangle$, plus $0.44 \mathrm{~mm}-\mathrm{MnCl}_{2} ; \bigcirc$, minus $\mathrm{MnCl}_{2}$ plus activating protein (coincident with curve with neither $\mathrm{MnCl}_{2}$ nor activating protein). Gas samples $(0.5 \mathrm{ml})$ were removed sequentially from reaction vessels at the times shown; control tests in which individual bottles were sampled at each time gave the same response within experimental error.

of the increase in total nitrogen of the organism and the consumption of malate as carbon substrate in a known period during the exponential phase of growth of $S$. lipoferum. As the culture was growing on $\mathrm{N}_{2}$ at a constant $P_{\mathrm{O}_{2}}$, we consider the data more meaningful than earlier data obtained with cultures growing under a variable $P_{\mathrm{O}_{2}}$; the efficiencies we observed are in the range reported for other aerobic $\mathrm{N}_{2}$-fixing bacteria (Mulder \& Brotonegoro, I974).

The percentage of nitrogen in dry cells that had been grown under $\mathrm{N}_{2}$-fixing conditions was only 4 to $5 \%$, whereas $\mathrm{NH}_{4} \mathrm{Cl}$-grown organisms contained 9 to $10 \%$ nitrogen. This low percentage of nitrogen in $\mathrm{N}_{2}$-grown cells reflects their high poly- $\beta$-hydroxybutyrate content (Y. Okon et al., unpublished observations).

Measurements of acetylene reduction at different stages of growth gave only relative values, because transfer of samples to stoppered bottles altered the rates of acetylene reduction by changing the cell environment. However, maximum acetylene reduction rates were observed for samples taken from the cultures grown at the optimal $P_{\mathbf{O}_{2}}$ of 0.005 to $0.007 \mathrm{~atm}$ (Table I).

Nitrogenase activity measured in cell-free extracts of $S$. lipoferum was affected by $\mathrm{Mg}^{2+}$ and $\mathrm{Mn}^{2+}$ in the reaction mixture (Fig. $2 a, b$ ). No nitrogenase activity was observed with less than $6 \cdot 0 \mathrm{mM}-\mathrm{MgCl}_{2}$; above this concentration nitrogenase activities increased sharply until an optimal level of 13.5 to $15.5 \mathrm{~mm}^{-\mathrm{MgCl}_{2}}$ was reached. Concentrations above I6. $\mathrm{mM}-\mathrm{MgCl}_{2}$ were inhibitory. Addition of $\mathrm{MnCl}_{2}$ to the reaction mixture (with $\mathrm{MgCl}_{2}$ present) enhanced nitrogenase activity, the optimal concentration being $0.44 \mathrm{~mm}-\mathrm{MnCl}_{2}$.

Concentrations of dithionite above $\mathrm{I} \mathrm{mg} / \mathrm{I} \cdot 35 \mathrm{ml}$ reaction mixture (about $4.3 \mathrm{~mm}$ ) inhibited nitrogenase (Fig. $2 c$ ). Dithionite samples from various commercial sources were used to prepare anaerobic solutions, and all produced the same effect. The $\mathrm{pH}$ and volume of the reaction mixtures were constant for these assays.

The optimal $\mathrm{pH}$ for nitrogenase activity was from $7 \cdot \mathrm{I}$ to $7 \cdot 4$; preparations were inactive below pH 6.5 and above $\mathrm{pH} 8.2$ (Fig. $2 d$ ). Nitrogenase in cell-free extracts from S. lipoferum was saturated at about 0.04 atm of acetylene and an apparent $K_{\mathrm{m}}$ of $0.0036 \pm 0.0004 \mathrm{~atm}$ 


\section{Table 2. Nitrogenase activity in different fractions of an extract from $S$. lipoferum, and cross-reactions with $\mathrm{Fe}$-protein from several $\mathrm{N}_{2}$-fixing bacteria}

Specific activities [expressed as nmol ethylene produced $\min ^{-1}(\mathrm{mg} \text { protein })^{-1}$ ] were derived from the amount of product formed between 20 and $30 \mathrm{~min}$ of the assay and the protein content of crude extract of $S$. lipoferum. Concentrations of Fe-protein from supplementing bacteria were not determined, but these proteins were free of any background activity. The Fe-proteins used were tested for activity with their homologous MoFe-proteins at the time of the experiment. The 'inactive' Fe-protein of $R$. rubrum was activated by the activating protein remaining in the extract from $S$. lipoferum after storage at $-18^{\circ} \mathrm{C}$; activated Fe-protein of $R$. rubrum supplemented the $\mathrm{MoFe}-$ protein of $S$. lipoferum to generate nitrogenase.

Crude extract; supernatant after centrifuging at $10000 \mathrm{~g}$ for $20 \mathrm{~min}$ Specific activity $8 \cdot 0$

Soluble nitrogenase; supernatant after centrifuging the crude extract at $48000 \mathrm{~g}$ for $2 \mathrm{~h}$

Membranes; resuspended pellet after centrifuging the crude extract at $48000 \mathrm{~g}$ for $2 \mathrm{~h}$

Crude extract stored 5 days at $-18^{\circ} \mathrm{C}$

$10 \cdot 0$

$0 \cdot 0$

Addition to crude extract of $S$. lipoferum after 5 days storage:

A. vinelandii Fe-protein

$R$. rubrum activated Fe-protein

$R$. rubrum 'inactive' Fe-protein

9.0

$B$. polymyxa Fe-protein

C. pasteurianum $\mathrm{Fe}$-protein

$\left(\mathrm{I} \cdot 3 \times 10^{-4} \mathrm{M}\right)$ was obtained from a reciprocal plot of activity against acetylene concentration. Higher $K_{\mathrm{m}}$ values for acetylene have been reported for a partially-purified nitrogenase of $A$. vinelandii: $0.012 \mathrm{~atm}$ (Rivera-Ortiz \& Burris, 1975), and 0.002 to $0.009 \mathrm{~atm}$ (Hardy, Burns \& Parshall, 1971). As the $K_{\mathrm{m}}$ for acetylene depends on the MoFe:Fe-protein ratio (Shah, Davis \& Brill, 1975), the relatively low apparent $K_{\mathrm{m}}$ observed for $S$. lipoferum nitrogenase may indicate a high $\mathrm{MoFe}: \mathrm{Fe}$-protein ratio.

We observed a non-linear time course of the activity of S. lipoferum nitrogenase with acetylene as a substrate in all our cell-free extracts (Fig. 3). Nitrogenase activity was enhanced by $\mathrm{MnCl}_{2}$ and by a purified protein from $R$. rubrum (Ludden \& Burris, 1976) capable of activating the Fe-protein of nitrogenase (Fig. 3).

Specific activities for nitrogenase of $\mathrm{Io}$ nmol ethylene produced $\mathrm{min}^{-1}$ (mg protein) ${ }^{-1}$ were obtained when the enzyme was assayed under optimal conditions during the 20 to $30 \mathrm{~min}$ interval of the reaction after nitrogenase was fully activated. Nitrogenase was soluble; no activity was observed in the pellet obtained by centrifuging the crude extract at $48000 \mathrm{~g}$ (the membrane fraction, Table 2).

Extracts of $S$. lipoferum lost their nitrogenase activity rapidly on storage at $-18^{\circ} \mathrm{C}$. Addition of purified Fe-protein of nitrogenase from A. vinelandii, $R$. rubrum (previously treated with activating protein) or $B$. polymyxa restored nitrogenase activity to the inactive extracts (Table 2), whereas C. pasteurianum Fe-protein failed to do so.

For activity, S. lipoferum nitrogenase required $\mathrm{Mg}^{2+}$, ATP furnished by an ATP-generating system, a pH near neutrality, a reductant and anaerobic conditions, similar to other nitrogenase systems (Ljones, 1974). Like R. rubrum, S. lipoferum has a nitrogenase that is apparently activated during the assay, and the activation requires $\mathrm{Mn}^{2+}$ in the reaction mixture (Fig. 3). A purified activating protein from $R$. rubrum enhanced $S$. lipoferum nitrogenase activity, and a crude extract from $S$. lipoferum was capable of activating purified inactive 
Fe-protein from $R$. rubrum (Table 2); this emphasizes the similarity of the nitrogenase systems in the two organisms.

Adding Fe-protein from $A$. vinelandii to an extract of $S$. lipoferum inactivated by storage at $-18^{\circ} \mathrm{C}$, resulted in a specific activity five times higher than that of the active crude extract from $S$. lipoferum; this suggested that some of the Fe-protein had been lost or inactivated during the preparation of the extract from $S$. lipoferum cells. Nitrogenase of $S$. lipoferum is poorly protected from $\mathrm{O}_{2}$ (Day \& Döbereiner, 1976), and the rapid loss of nitrogenase on aeration of $\mathrm{N}_{2}$-fixing cells is apparently caused by inactativion of the $\mathrm{O}_{2}$-labile Fe-protein.

This investigation was supported by the College of Agriculture and Life Sciences, University of Wisconsin at Madison, by Public Health Service grant AI-00848 from the National Institute of Allergy and Infectious Diseases, and by the National Science Foundation grant

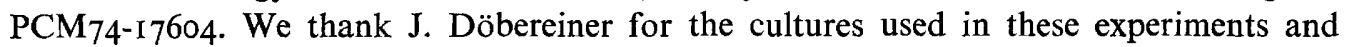
R. A. Zweifel for designing and building an $\mathrm{O}_{2}$-stat.

\section{REFERENCES}

Albrecht, S. L. \& OKon, Y. (1975). Nitrogen fixation by Spirillum lipoferum. Plant Physiology Supplement 56,73 .

Borkowski, J. D. \& Johnson, M. J. (1967). Long-lived steam-sterilizable membrane probes for dissolved oxygen measurement. Biotechnology and Bioengineering 9, 635-639.

BURRIS, R. H. (1974). Methodology. In The Biology of Nitrogen Fixation, pp. 9-33. Edited by A. Quispel. Amsterdam, New York: North Holland Publishing Co.

DAY, J. M. \& DöBEREINER, J. (1976). Physiological aspects of $\mathrm{N}_{2}$-fixation by a Spirillum from Digitaria roots. Soil Biology and Biochemistry 8, 45-50.

DöBEREINER, J. \& DAY, J. M. (1976). Associative symbioses in tropical grasses: characterization of microorganisms and dinitrogen fixing sites. In Proceedings of the Ist International Symposium on Nitrogen Fixation, pp. 518-538. Edited by W. E. Newton and C. J. Nyman. Pullman, Washington, U.S.A.: Washington State University Press.

Fedorov, M. V. \& KalininsKaya, T. A. (1961). The relation of the nitrogen fixing Mycobacterium (Mycobacterium species 301 ) to various carbon sources and to additional factors. Mikrobiologiya $3^{0}, 7-1$ I.

GoA, J. (1953). A micro biuret method for protein determination. Determination of total protein in cerebrospinal fluid. Scandinavian Journal of Clinical Laboratory Investigation 5, 218-222.

HARDY, R. W. F., Burns, R. C. \& Parshall, G. W. (197I). The biochemistry of $\mathrm{N}_{2}$ fixation. In Bioinorganic Chemistry, pp. 219-247. Edited by R. F. Gould. Washington, D.C.: American Chemical Society.

LJoNes, T. (1974). The enzyme system. In The Biology of Nitrogen Fixation, pp. 61 7-638. Edited by A. Quispel. Amsterdam, New York: North Holland Publishing Co.

LUdDEN, P. \& BuRRIs, R. H. (1976). Science (in the Press).

MuldER, E. G. \& BROTONEGORO, S. (1974). Free-living heterotrophic nitrogen-fixing bacteria. In The Biology of Nitrogen Fixation, pp. 37-85. Edited by A. Quispel. Amsterdam, New York: North Holland Publishing Co.

Postgate, J. R. (197I). Fixation by free-living microbes: physiology. In The Chemistry and Biochemistry of Nitrogen Fixation, pp. 16I-190. Edited by J. R. Postgate. London, New York: Plenum Press.

RIVERA-ORTIZ, J. M. \& BuRRIS, R. H. (I975). Interactions among substrates and inhibitors of nitrogenase. Journal of Bacteriology 123, 537-545.

ShaH, V. K., DAVIS, L. C. \& BRILL, W. J. (1972). Nitrogenase. I. Repression and derepression of the ironmolybdenum and iron proteins of nitrogenase in Azotobacter vinelandii. Biochimica et biophysica acta 256, 498-5II.

ShaH, V. K., DAVIS, L. C. \& BrILL, W. J. (1975). Nitrogenase. VI. Acetylene reduction assay: dependence of nitrogen fixation estimates on component ratio and acetylene concentration. Biochimica et biophysica acta 384, 353-359.

Umbreit, W. W., BüRris, R. H. \& StaufFer, J. F. (1972). Manometric and Biochemical Techniques, (a) p. 268, (b) p. 259. Minneapolis, U.S.A.: Burgess Publishing Co.

VON BÜLow, J. F. W. \& DöBEREINER, J. (I975). Potential for nitrogen fixation in maize genotypes in Brazil. Proceedings of the National Academy of Sciences of the United States of America 72, 2389-2393. 